\title{
INDEPENDENT REPRESENTATION FOR CORPORATE DEFENDANTS IN DERIVATIVE SUITS*
}

The role of counsel for the corporation in derivative litigation has received scant attention. It is unclear whether an attorney may properly represent both the corporation and any directors or officers named as individual defendants in the suit. The Canons of Ethics state that attorneys should neither represent clients whose intereșts are adverse, nor compromise the confidences of present or former clients. ${ }^{1}$ Nevertheless, dual representation of corporate and insider defendants has frequently occurred, ${ }^{2}$ in part because the directors and officers usually select corporate counsel, and in part because the nature of the corporation's interests and the scope of its role in the derivative action are surrounded by confusion. Under American procedure the corporation is joined as a party defendant; ${ }^{3}$ yet it will receive any benefit or recovery resulting from a successful prosecution of the suit. Furthermore, while the corporation is usually only a nominal party, ${ }^{\mathfrak{b}}$ in certain circumstances it is

*Lewis v. Shaffer Stores, 218 F. Supp. 238 (S.D.N.Y. 1963).

1. Amrerican Bar Association, Canons of Professional Ethics 6 \& 37 (1957).

2. It is difficult to determine precisely how frequently this practice occurs. Washington and Bishop state that the corporation and individual insider defendants "often" retain common counsel. Washington \& Bishop, Indemanifying the Corrorate Executive 37, 41 (1963) [hereinafter cited as WASHINGroN \& BisHop]. Hornstein implics that the practice is fairly common. 2 Hornstern, Corporatron Law and Practice \& 714 (1959, Supp. 1964) [hereinafter cited as HoRnsteIN]. An examination of reported derivative suits also indicates that instances in which the insider defendants and the corporation were repre. sented by the same counsel are numerous indeed. However, in a majority of cases, tho corporate and individual defendants appear to have been separately represented.

Dual representation may occur in several forms. A single attorney or firm of attorncys may be the sole counsel representing both the individual and corporate defendants. Alternatively, counsel for the corporation may only assist in the insiders' defense. Such is the case when the insiders also retain outside counsel to represent their interests. The ethical problems are much the same in both situations, and the term "dual representation" is in" tended to include both variants of the practice.

3. 2 HorNSTEIN \& 714; Groel v. United Elec. Co., 70 N.J. Eq. 616, 625, 61 Atl، 1061, 1064 (Ch. 1904); General Inv. Corp. v. Addinsell, 255 App. Div. 319, 7 N.Y.S.2d 377, motion for reargument denied, 255 App. Div. 962, 8 N.Y.S.2d 671 (1938). See notes 27-28 infra.

4. Taormin v. Taormin Corp., 32 Del. Ch. 18, 78 A.2d 473 (Ch. 1951); Kecnan v. Eshleman, 23 Del. Ch. 234, 2 A.2d 904 (1938). Cf. Clarke v. Greenberg, 296 N.Y. 146, 71 N.E.2d 443 (1947). Only in exceptional circumstances have courts allowed the complaintunt to recover a pro rata amount of the sum recoverable. See Perlman v. Feldman, 219 F.2d 173, cert. denied, 349 U.S. 952 (1955); Matthews v. Headley Chocolate Co., 130 Md. 523, 100 Atl. 645 (1917).

5. E.g., Leven v. Birrell, 92 F. Supp. 436, $444-45$ (S.D.N.Y. 1949); Meyers v. Smith, 190 Minn. 157, 251 N.W. 20 (1933); Chaplin v. Selznick, 186 Misc. 66, 58 N.Y.S.2U 453 (Sup. Ct. 1945). 
allowed to take an active role in the litigation, which may range from outright aid to the plaintiff ${ }^{6}$ to defense on the merits.

The question of the propriety of dual representation was sharply presented in a recent derivative suit, Lewis $v$. Shaffer Stores. ${ }^{8}$ The action was brought by a stockholder of the $\mathrm{R}$. C. Williams Company against the officers, directors and a majority shareholder of the corporation. The thrust of the complaint was two-fold: to recover short-swing profits made by the individual defendants in the purchase and sale of Williams' securities, and to recover losses allegedly suffered by Williams as a result of certain transactions initiated under the defendants' control. A large New York City law firm, which had been counsel to Williams for many years, appeared on behalf of the corporation and the individual defendants and filed a joint answer denying the charges of wrongdoing. At this juncture, the complaining shareholder moved to strike the company's answer and to strike the appearance of the law firm as counsel for Williams. Plaintiff further demanded that the company appear by "genuinely independent counsel."

The court acceded to the plaintiff's request that the dual representation of parties defendant be discontinued, and ordered that Williams "retain independent counsel, who have had no previous connection with the corporation, to advise it as to the position which it should take in this controversy."10 In a brief opinion Judge McLean first noted that he had no doubt that the law firm in question believed "in good faith" that the suit was without merit."1 From this remark, it may be inferred that the firm, and perhaps the court, considered the interests of the corporation and individual defendants to be so completely merged in cases in which the plaintiff has no valid cause of action that counsel could represent both clients with clear conscience. But pointing to the plaintiff's vigorous contention that the suit was meritorious, Judge McLean reasoned that the court "cannot and should not attempt to pass upon the merits at this stage."12 Consequently, he grounded his decision to require separate counsel on the fact that, "upon the face of the complaint," the interests of the officers, directors and majority shareholders were "clearly adverse ... to the interests of the stockholders other than defendants."13 Since such adversity of interest is typically manifested in shareholders' complaints, and since most courts will be equally reluctant to reach the merits at an early

6. Block v. Propp, 174 Misc. 122, 19 N.Y.S.2d 895 (Sup. Ct. 1939).

7. Otis \& Co. v. Pennsylvania R.R., 57 F. Supp. 680 (E.D. Pa. 1944).

8. 218 F. Supp. 238 (S.D.N.Y. 1963).

9. Id. at 239. The plaintiff also asked the court to limit the answer to be filed by the independent counsel to a mere "invitation to the plaintiff to prove his case to the end that the corporation receive any benefits to which it is entitled." Ibid.

10. Id. at 240 . The court pointedly refused to allow the plaintiff to dictate the nature of the answer to be filed by the independent counsel.

11. Ibid.

12. Ibid. Compare Smith v. Sperling, 354 U.S. 91,95 (1956).

13. Lewis v. Shaffer Stores, 218 F. Supp. 238, $239-40$ (S.D.N.Y. 1963). 
stage, adoption of the Lewis court's ethical viewpoint would bar dual representation in most derivative actions.

It cannot be said, however, that Lewis reflects the uniform position regarding the propriety of counsel representing both corporate and individual defendants. ${ }^{14}$ The earlier approach of the courts was characterized by a marlied reluctance to disturb the practice of dual representation in derivative suits. ${ }^{10}$ The reason given was that the corporation has the right to "select such counsel as it chooses."16 The first major retreat from this tolerant attitude was the decision of the New York Appellate Division in Garlen v. Green Mansions, Inc. ${ }^{17}$ In that case it was held that when relief sought in a shareholder's complaint requires an active appearance and answer by the corporation, such appearance must be by independent counsel. This rule, which may be read to permit dual representation in the more usual case where the corporation is only a nominal party, is now generally followed in the State of New York.18

Since the Garlen decision in 1959, there has been an increasing sensitivity to the possible conflict of interest generated by dual representation in derivative litigation, and a definite movement towards a more complete prohibition of the practice is discernible. The Lewis case, of course, is the most striking example of this trend. In addition, the influential Committee on Professional Ethics of the Association of the Bar of the City of New York has stated in Opinion 842 that

a conflict of interests is inherent in any [derivative] action whenever relief is sought on behalf of the corporation against the individual directorofficer defendants, and that in such cases Canon 6 precludes one firm from representing both the corporation and the individual director-officer defendants except in unusual circumstances stemming from particular facts in a given case. ${ }^{10}$

14. The variety of judicial treatment of dual representation is stressed in Tockman, The Position of Corporate Counsel in Derivative Actions, 51 ILL. B.J. 654, $659-60$ (1963), and Osborn, Developments in Corporate Law, 19 Bus. Law. 577 (1964).

15. See Otis \& Co. v. Pennsylvania R.R., 57 F. Supp. 680 (E.D. Pa. 1944); Hornsby v. Lohmeyer, $364 \mathrm{~Pa}$. 271, 72 A.2d 294 (1950).

16. Otis \& Co. v. Pennsylvania R.R., supra note 15 , at 684 . The Otis court also questioned a shareholder's standing to object to the corporation's choice of counsel, on grounds that the shareholder had never sustained a relationship of confidence to the attorneys in question. Ibid. However, the requirement of an attorney-client relationship should not be allowed to bar a shareholder from challenging the adequacy of the corporation's representation in a derivative suit brought against directors and officers. The insider defendauts can hardly be expected to complain that it is improper for the corporation's counsel to represent their own personal interests. Thus, prohibiting the shareholder's objcction to dual representation is generally tantamount to prohibiting any effective objection in behalf of the corporation.

17. 9 App. Div. 2d 760, 193 N.Y.S.2d 116 (1959) (per curiam).

18. See Kelley v. 74 \& 76 West Tremont Ave. Corp., 24 Misc. $2 d$ 370, 198 N.Y.S.2d 721 (Sup. Ct. 1960).

19. 15 RECORD of N.Y.C.B.A. 80 (1960). The statement cited expresses the majority view of the Committee. It should be noted that Opinion 842 overruled portions of a previous opinion issued in 1936 , which stated that

there seems to be no objection to the attorney's representing both the corporation and the directors in the [derivative] action, provided, of course, that there is no 
Recent cases before Chancellor Seitz in the Chancery Court of Delaware 20 and Judge Washington in the D.C. Circuit Court of Appeals ${ }^{21}$ also indicate that the corporate and individual defendants should be separately represented. 22 In sum, if the complaining shareholder of the future makes an objection to counsel's representation of both corporate and insider defendants, there is a good chance his motion will be granted. Two further points warrant emphasis. First, if the shareholder delays in raising his objection, the courts will be considerably less receptive to his plea; in a number of cases the courts have refused to bar dual representation essentially because the plaintiff waited until late in the proceedings before asking that the corporation be separately represented. ${ }^{23}$ Second, the practice of dual representation undoubtedly continues. And in cases where the complaining shareholder voices no objection, courts have yet to demonstrate a willingness to require independent counsel sua sponte.

In view of this developing trend towards the prohibition of dual representation in derivative suits, it is appropriate to examine more closely the factors which allegedly render the practice unethical. The problem, of course, is not the interpretation of the Canons of Ethics, for Canons 6 and 37 adequately set forth the relevant strictures against representing conflicting interests and compromising clients' confidences. ${ }^{24}$ On the contrary, the essential problem

conflict of interest between the corporation and the directors represented by him. Conatittee on Professional Ethics of the Assoctation of the Bar of the City of New York aNd the New York County Lawyers' Association, Opinion 368 (1956).

20. Essential Enterprises Corp. v. Dorsey Corp., 182 A.2d 647, 654 (Del. Ch. 1962 ).

21. Murphy v. Washington Am. League Baseball Club, Inc, 324 F.2d 394, 398 (D.C. Cir. 1963).

22. See also Milone v. English, 306 F.2d 814 (D.C. Cir. 1962). Under the LaborManagement Reporting and Disclosure Act of 1959, 73 Stat. 535 (1959), 29 U.S.C. § 501 (b) (Supp. II, 1959-60), a union member may initiate a suit in behalf of his union against any union officers who have been derelict in their duty. The act clearly confers rights upon members which resemble a shareholder's right to maintain a derivative action against corporate management. Thus, it is significant that the court in Mfilone said:

Counsel who are chosen by and represent officers charged with misconduct, and who also represent the union, are not able to guide the litigation in the best interest of the union because of the conflict in counsel's loyalties. In such a situation it would be incumbent upon counsel not to represent both the union and the officers.

Id. at 817. Accord, Comprittee on Professional Etaics of The Assoctation of the Bar of the City of New YoRk, OfInIoN 843, 15 Record of N.Y.C.B.A. 139 (1960).

23. Solomon v. Hirsch, 35 Misc. 2d 716, 230 N.Y.S.2d 625 (Sup. Ct. 1962); Kelley v. 74 \& 76 West Tremont Ave. Corp., 24 Misc. 2d 370, 198 N.Y.S.2d 721 (Sup. Ct. 1960); Hausman v. Buckley, 299 F.2d 696 (2d Cir.), cert. denicd, 369 U.S. 885 (1962) ; SelamaDindings Plantations, Ltd. v. Durham, 216 F. Supp. 104 (S.D. Ohio 1963). See Mfarco v. Dulles, 169 F. Supp. 622, 632 (S.D.N.Y.), appeal dismissed, 268 F.2d 192 (2d Cir. 1959), where it is pointed out that "a motion to disqualify [counsel] is of an equitable nature. $A$ party making such a motion should do so with reasonable diligence and promptness after the facts have become known to it."

24. Canon 6 reads in part:

It is unprofessional to represent conflicting interests, except by express consent of all concerned given after a full disclosure of the facts. Within the meaning of 
is one of applying the generalized principles enunciated in the canons to the specific context of the derivative suit. An initial difficulty is created by the complex interrelationships that exist between an attorney and the shareholders, directors and officers who comprise the corporation. It seems clear that a conceptualization of the corporation as a separate entity capable of treatment as an ordinary client ignores these relationships and consequently restlts in too simplistic a resolution of the ethical issue of dual representation. Nowhere, in fact, is the fallacy of treating the corporation as an ordinary client more clearly demonstrated than in reference to the consent provisions contained in Canons 6 and 37. These provisions permit representation of conflicting interests or possible disclosure of confidences upon the informed and express consent of all concerned. But it would be meaningless in derivative litigation to allow the consent of the parties defendant to exculpate the practice of dual representation, for most often it would be the defendant directors and officers who would force the corporation's consent. Indeed, Opinion 842 pointedly warns that the "unique relationship existing between the corporation and its directors is such that extreme caution should be exercised in resorting to the 'consent' provisions . ...."25

Because of the inadequacies of the concept of the corporation as an entity, an inquiry into the propriety of dual representation must "pierce the corporate veil" and determine the real nature of the confidences and interests of the corporate client. Viewed in this light, the hazard that dual representation

this canon, a lawyer represents conflicting interests when, in behalf of one client, it is his duty to contend for that which duty to another client requires him to oppose.

The obligation to represent the client with undivided fidelity and not to divulge his secrets or confidences forbids also the subsequent acceptance of retainers or cmployment from others in matters adversely affecting any interest of the client with respect to which confidence has been reposed.

Canon 37 essentially reiterates the precept set forth in the last paragraph of Canon 6:

It is the duty of a lawyer to preserve his client's confidences. This duty outlasts the lawyer's employment, and extends as well to his employees; and neither of them should accept employment which involves or may involve the disclosure or use of these confidences, either for the private advantages of the lawyer or to the disadvantage of the client, without his knowledge and consent, and even though there are other available sources of such information. A lawyer should not continue cmploy. ment when he discovers that his obligation prevents the performance of his full duty to his former or to his new client.

Amirrican Bar Assoctation, Canons of Professional Entuics (1957).

The canons are given the force of statutory law in many jurisdictions. E.g., S.D.N.Y. General Rule 5(c), 16 FED. Rules SERv. 908 (1952). Prohibitions similar to those contained in Canons 6 and 37 are also incorporated in various state statutes regulating the conduct of the Bar, e.g., CAL. Bus. \& Prof. CoDE $\$ 6068(\mathrm{e})$; $\S 6076$, Rules 5 \& 7.

But irrespective of the Canons or statutory enactment, courts are justified in prohibiting counsel from representing conflicting interests or violating a client's confidence, for such practices are clearly violative of public policy. See In re Boone, 83 Fed. 944, 952 (N.D. Cal. 1897). See generally Drunker, LeGAl ErHICs 59-60 (1953) [hereinafter cited as DrINKer].

25. 15 RECORD OF N.Y.C.B.A. 80 (1960). 
may lead counsel to violate the confidences of his corporate client seems largely academic. In most cases, the confidences between the corporation and its counsel are totally accessible to director and officer defendants. For this reason, a concern that counsel will act as a conduit for corporate confidences is unrealistic. Equally illusory is the potential for breached confidences when former or present corporate counsel undertake to represent only the insider defendants in a derivative suit. This precise question was considered in Lewis v. Shaffer Stores. Significantly, although dual representation was ruled improper in that case, the law firm was allowed to continue its representation of the individual defendants. The court saw "no impropriety" in such representation, especially since the firm felt an "obligation to defend the officers and directors whom it has advised."26 This holding indicates that the policy that an attorney stand by his client is a more pressing goal than a mechanical application of Canon 37 and re-emphasizes the point that the danger that corporate confidences may be channelled through counsel to director-officer defendants is minimal indeed.

A more tangible ethical problem of dual representation is presented by the possibility of a conflict of interest between the corporation and the individual defendants. The fact that, under American procedure, the corporation is joined as a defendant is a product of the historical development of the derivative suit. ${ }^{27}$ This alignment, however, does not necessarily reflect the theoretical interests of the corporation. ${ }^{28}$ The corporation is the ultimate recipient of any benefit or recovery that may be derived from the suit; it stands to gain at the expense of the individual defendants. Thus, in the theoretical model of the derivative suit, a counsel who undertakes dual representation violates the mandate of Canon 6 , since "in behalf of one client it is his duty to contend for that which duty to another client requires him to oppose."

It may seem, however, that a finding of impropriety based on this inherent conflict of interest fails to take into account the realities of derivative litigation. In the first place, the mechanism of the derivative suit is undoubtedly abused. The well known Wood Survey revealed that the strike suitor - eager to trade his nuisance value for a quick and secret settlement - may have been the

26. Lewis v. Shaffer Stores, 218 F. Supp. 238, 239 (1963); accord, Marco v. Dulles, 169 F. Supp. 622 (S.D.N.Y.), appeal dismissed, 268 F.2d 192 (2d Cir. 1959).

27. The alignment of the corporation as a defendant was probably dictated by the traditional reluctance in American theory to allow an unwilling litigant to be brought in as a plaintiff. 2 HORNSTEIN $\$ 714$.

28. It is significant that it is the customary English practice to align the corporation as a party plaintiff. Duckett v. Glover, $6 \mathrm{Ch}$. D. 82 (1877). Furthermore, among many commentators, and in the federal courts, there has been pressure to align the corporation as a plaintiff when it appears that it is not truly antagonistic to the sharcholder's cause. See Sullivan, The Federal Courts as an Effective Forum in Shareholders Derivalive Actions, 22 LA. L. Rev. 580, 595 (1962). See generally 3 Mroore, Federal Practicz II 23.21 (2d ed. 1963). But see Smith v. Sperling, 354 U.S. 91 (1957), and a companion case, Swanson v. Traer, 354 U.S. 114 (1957). 
rule rather than the exception prior to $1944 .^{28}$ Although many jurisdictions have placed considerable obstacles in the path of the litigious shareholder, strike suits remain prevalent. ${ }^{31}$ Secondly, opinions abound with the statement that the corporation is only a nominal or neutral party in derivative actions. 02 It may be argued from these premises that it is unreasonable and wastefully expensive to require separate counsel to represent the corporate and individual defendants, because their interests are in virtual harmony whenever the action is without merit, and because the corporation will remain a netitral party whose counsel is generally unable to alter the outcome of the litigation. To allow the shareholder to force the corporation and the individual defendants into the burdensome procedure of retaining independent counsel will accomplish little and merely adds another weapon to the arsenal of the strike suitor.

On the other hand, it must be realized that in a significant number of derivative suits the corporation actually assumes an active role. For example, in a number of instances corporations have aided the plaintiff shareholder by assisting in the prosecution of the claim..$^{33}$ Alternatively, the corporation may set up certain procedural defenses that may be "practically as prejudicial to the plaintiff's chances of success as an active defense on the merits." ${ }^{14}$ Thus, the corporation may object to lack of proper service, ${ }^{85}$ complain of misjoinder of causes of action, ${ }^{86}$ move that the plaintiff be required to post sccurityfor-expenses ${ }^{37}$ or allege that demand on the directors or shareholders was

29. Wood, Survey and Report Regarding Stockholders' Derivative Suits (1944). The prevalence of strike suits at the time of the survey is indicated by Wood's finding that "the ratio of recoveries to dismissals in cases involving publicly held corporations is approximately 1 to 17 ; in those involving closely held corporations this ratio is only about 1 to $4 . " I d$. at 7. The findings of the survey, however, have been severely criticized. Sco Hornstein, The Death Knell of Stockholders' Derivative Sutits in Nev York, 32 Carrw. L. REv. 123 (1944).

30. In force in New York, for example, is a security-for-expenses statute, N.Y. Bus. CoRp. LAW $\S 627$ (1963), and a requirement of contemporaneous stock ownership, N.Y. Bus. Corp. Law § 626(b) (1963).

31. Although rules such as FED. R. CIv. P. 23(c) have largely eliminated opportunitica for secret settlement, the lucrative fees awarded plaintiff's counsel, which often amount to 20 per cent of the fund recovered for the corporation, remain a substantial inducement to shareholder suits. See generally Hornstein Legal Therapeutics: The "Salvage" Factor in Counsel Fee Awards, 69 Harv. L. Rev. 658 (1956) ; Hornstein, The Counsel Fee in Shareholders' Derivative Suits, 39 CoLum. L. REv. 784 (1939).

32. See note 5 supra and accompanying text.

33. Block v. Propp, 174 Misc. 122, 19 N.Y.S.2d 895 (Sup. Ct. 1939); Sheridan v. Sheridan Elec. Light Co., 38 Hun. 396 (N.Y. Sup. Ct. 1886) ; cf. Silverman v. Re, 194 F. Supp. 540 (S.D.N.Y. 1961).

34. WASHINGTON \& BisHop 49. See generally Washington, Stockholders' Derivative Suits: The Company's Role and a Suggestion, 25 CorNelz L.Q. 361 (1940); Note, Defenses in Shareholders' Derivative Suits - Who May Raise Them, 66 HARv. L. Rev. 342 (1952).

35. Carruthers v. Jack Waite Mining Co., 306 N.Y. 136, 116 N.E.2d 286 (1953).

36. Brock v. Poor, 216 N.Y. 387, 111 N.E. 229 (1915).

37. Generally, only the corporation can move to compel security. See, e.g., N.Y. Bus. CORP. LAW § 627 . 
absent or inadequate. ${ }^{38}$ Finally, in certain circumstances - which a permissive judiciary has allowed to expand considerably - the corporation may be allowed to enter what is in effect an active defense on the merits. ${ }^{\text {os }}$ Such a defense might be permissible where the complaint seeks to enjoin the performance of contracts, ${ }^{40}$ or seeks to interfere with a corporate reorganization, 11 or prays for the appointment of a receiver. ${ }^{42}$ The range of possible corporate responses to derivative actions and the obvious fact that corporate harassment of the plaintiff is of great advantage to the accused insiders places an attorncy who represents both corporate and individual defendants in an ambivalent position. Certainly it is an important function of counsel to advise the corporation regarding its proper stance in the controversy. ${ }^{13}$ But can an attorney render truly impartial advice to the corporate client where the interests of his individual clients will inevitably be affected by the character of the corporation's response to the suit ?44 This problem is in no way lessened by the frequency of strike suits, for counsel must still distinguish between these and truly meritorious actions, and in making this distinction counsel must remain free from any bias in favor of his individual clients. ${ }^{15}$

The practical difficulties with dual representation extend beyond counsel's advisory function. There is of course the striking conflict of interest that would be created by counsel's representing all parties defendant in a meritorious cause of action. A less obvious, but equally important, problem arises at the crucial stage of settlement, where a major portion of derivative actions is concluded.46 It is at this stage that the adversary process is most likely to break down. When cases are brought to trial, the plaintiff's counsel can generally be relied upon to represent shareholder interests by vigorous prose-

38. Quirke v. St. Louis-S. F. Ry., 277 F.2d 705 (8th Cir. 1960).

39. E.g., Otis \& Co. v. Pennsylvania R.R, 57 F. Supp. 680 (E.D. Pa. 1944); Blish v. Thompson Automatic Arms Corp., 30 Del. Ch. 538, 64 A.2d 581 (Sup. Ct. 1948). See authorities cited notes $40-42$ infra.

40. Kirby v. Schenck, 25 N.Y.S.2d 431 (Sup. Ct. 1941).

41. Corey v. Independent Ice Co., 226 Mass. 391, 115 N.E. 488 (1917).

42. Esposito v. River Sand \& Gravel Co., 287 Mass. 185, 191 N.E. 363 (1934); Godley v. Grandall \& Godley Co., 181 App. Div. 75, 168 N.Y.S. 251 (1917).

43. Significantly, Opinion 842 stresses the importance of separate counsel at the crucial period in which the corporation must determine its role in the controversy:

[W] herever the facts are such as to make it improper for the same attorney to represent both classes of defendants throughout such an action, it would be equally improper for the same attorney to represent the two classes of defendants even for a short period of time.

15 ReCORD of N.Y.C.B.A. 80, 81 (1960).

44. It must be realized that, in situations of dual representation, there is a natural tendency for counsel to favor the interests of his individual clients. Since the officers and directors usually select corporate counsel, an attorney who gives preference to the inanimate body corporate will run the risk of being dismissed by both corporate and individual clients.

45. See Milone v. English, 306 F.2d 814, 817 n.1 (D.C. Cir. 1962).

46. See Hornstein, The Death Kuell of Stockholders' Derizative Strils in New York, 32 CALIF. L. REv. 123, 127-28 (1944). 
cution of the corporation's cause of action. But at settlement the probability that plaintiff's counsel will be interested only in obtaining a lucrative fee may undermine his capacity to represent adequately the corporation's shareholders. Although the measure of counsel's compensation is dependant upon the size of the fund recovered for the corporation, the skill and the amount of time expended by counsel are limiting factors in determining his fee. ${ }^{47}$ Past a certain point, any increases in the fund recovered for the corporation may not significantly increase the fees awarded counsel; otherwise counsel's compensation would be wholly out of proportion to the services he has rendered. Thus, the incentive of plaintiff's counsel to press for the largest possible recovery for the corporation may be diminished. ${ }^{48}$ At this juncture, where plaintiff's counsel and the individual defendants have a common interest in the quick termination of settlement negotiations, the character of the corporation's representation assumes crucial importance. If the same counsel represents both the corporation and the director and officer defendants, the interests of the corporation are likely to receive insufficient protection. An increased recovery for the corporation is wholly incompatible with the goal of limiting the defendants' liability. Defendants' counsel is thus placed in an untenable position, and more often than not he will succumb to the pressture to approve any settlement between the shareholder and his individual clients. On the other hand, where the corporation is separately represented, it is more likely that counsel will reach an independent judgment regarding the merits of any settlement proposal. Should counsel then conclude that the settlement is inadequate, he may be able to force the defendants to increase the sum to be paid the corporation. At the very least, where notice to shareholders or court approval of settlement is required, ${ }^{40}$ an independent counsel will be able to draw attention to inadequacies in the settlement agreement. ${ }^{60}$

In addition to the ethical impropriety of dual representation, a major difficulty with the practice occurs in the context of indemnification of corporate executives. Generally, directors or officers found guilty in a derivative suit

47. Cherner v. Transitron Electronic Corp., 221 F. Supp. 55, 61 (D. Mass. 1963).

48. See Alleghany Corp. v. Kirby, 333 F.2d 327, 347 (2d Cir. 1964) (Friendly, J, dissenting).

49. E.g., Fed. R. Civ. P. 23 (c); Ariz. R. Civ. P. 23(c); Texas R. Civ. P. 42(d). See Whitten v. Dabney, 171 Cal. 621, 631-32, 154 Pac. 312, 316 (1915) ; Spellacy v. Superior Court, 23 Cal. App. 2d 142, 72 P.2d 262 (1937).

50. An equally useful role could be performed by an independent counsel with regard to the compensation allowed plaintiff's attorney. As suggested in Cherner v. Transitron Electronic Corp., 221 F. Supp. 55, 61 (D. Mass. 1963), the shareholders may not havo adequate means to object to the size of the fees awarded plaintiff's counsel. In such instances the adversary process cannot be relied upon to keep the fees within reasonablo bounds, for the defendants may be indifferent to the percentage of the damages which will be diverted to complainant's counsel. Clearly, an independent counsel responsible only to the corporation would be more willing, and better able, to challenge excessive counsel feo awards than an attorney who had also undertaken the representation of the individual defendants. 
cannot be reimbursed by the corporation for the expense of their defense.51 But if the same counsel represents both the corporate and insider defendants, it is difficult to segregate legal services performed for the corporation from those performed on behalf of the insiders. ${ }^{52}$ Thus the corporation may readily finance the insiders' defense by paying a proportionately larger share of the legal expenses than is merited by its role in the litigation. The pressure to use dual representation as a means to transfer the insiders' defense expenses to the corporation has undoubtedly been lessened by the trend toward greater liberality in statutory indemnification provisions. The Delaware Act ${ }^{23}$ and the Model Corporation Act, ${ }^{54}$ for example, provide the corporation with a virtual carte blanche in providing for indemnification of executives. ${ }^{\circ}$ Nevertheless, the indemnification problem in situations of dual representation retains considerable vitality. Although the indemnification statutes generally do not allow the corporation to finance the insiders' defense during the suit, this result may readily be accomplished through the retention of common counsel. In such instances, if the insider defendants are ultimately found liable, recovery of the corporate funds expended in their defense might prove impossible.

In summary, the strictures against dual representation enunciated in Lcavis v. Shaffer Stores and Opinion 842 are justified by both the theory and reality of derivative litigation. But the question of how a court can implement a decree barring dual representation remains. The only solution presented by decisions to date is illustrated by the order of the Lewvis case: the corporation was simply advised to "retain independent counsel who have had no previous connections with the corporation."

An alternative solution might be to require the insiders to secure new counsel, thus permitting the corporation to retain its original counsel. ${ }^{63}$ But while this procedure removes the outward appearances of dual representation, the substance of the wrong remains. A residual bias in favor of the individual defendants might continue to undermine counsel's judgment. This potential bias would stem from the fact that counsel's first loyalty might remain with the directors and officers of the corporation, who have been his principal contact with the inanimate corporate client in the past. In addition, counsel

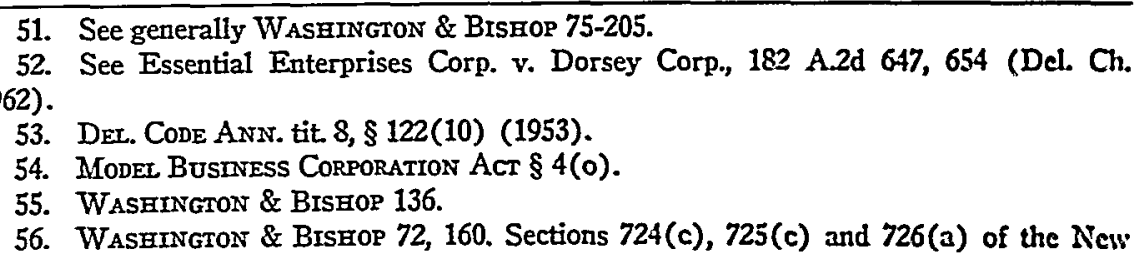
York's new Business Corporation Act are unique in permitting the corporation to advance the insiders' defense expenses, subject of course to repayment should the insiders be found guilty.

57. 218 F. Supp. 238, 240 (S.D.N.Y. 1963).

58. This alternative has not been considered in the cases, perhaps because it is usually counsel's appearance for the corporation which provokes the shareholder's objection to dual representation. 
might fear that rendering advice antagonistic to the insiders' interests would impair future relations with his corporate client. For these reasons, the Lewis decision to have the corporation secure new counsel seems the sounder alternative. ${ }^{59}$

Still it must be realized that even the Lewis order provides but a limited remedy. It is true that the order effectively eradicates any ethical impropriety stemming from dual representation and also removes the opportunity for circumventing the policy of the indemnification statutes. But there remains a more fundamental problem caused by the potential divergence between the welfare of the corporation and the personal interests of the officer and director defendants. Since the officers and directors generally conduct the corporate entity, there is always a danger that a corporation will be directed to act in a manner which fails to protect its best interests. This problem, which underlies virtually every aspect of derivative litigation, would natturally affect both the selection and performance of an independent corporate counsel. For example, the Lezeris court refused to supervise the selection of the independent counsel. In the view of the court, "the fact that the selection of such independent counsel will necessarily be made by officers and directors who are defendants" did not "present any insuperable difficulty."60 Despite the optimism of the court, it seems likely that in many instances the corporate counsel chosen will be the mere pawn of the insider defendants. Similarly, under the Levis order the directors apparently retain the power to remove the independent attorney; the threat of dismissal might frequently deter counsel from providing the fullest protection to the interests of his corporate client.

If the independent counsel is to be safeguarded from pressure to stibordinate the welfare of the corporation to the personal interests of the insider defendants, the Lewis decree must be bolstered. Before formulating a procedure to this end, however, it is necessary to analyze the various interests at stake. Certainly a central concern is the protection of the private interests embodied in the corporate entity. The economic interests of the shareholder are of primary importance and demand adequate protection. The interests of the corporation's employees must also be considered. In addition, certain outside sectors of the community are affected by the institution and outcome

59. Of course, in some instances it may be impractical to require the corporation to retain new counsel. In particular, where the individual defendants are initially represented both by outside attorneys and by a corporate counsel whose role in their defense appears to be relatively minor, courts may be unwilling to go beyond a requirement that corporato counsel merely refrain from assisting the insider defendants.

60. Lewis v. Shaffer Stores, 218 F. Supp. 238, 240 (S.D.N.Y. 1963). The firm originally representing the Williams Company argued that such a decree "elevated form over substance." Affidavit of defendant's attorney, March 8, 1963, on file in the Federal District Court for the Southern District of New York.

It must be realized, however, that the mere act of requiring the corporation to retain independent counsel removes the "appearance of evil" inherent in the dual representation situation. To many, the elimination of practices which have the appearance of wrongdoing is as important to the maintenance of public confidence as the elimination of the actual abuse. See DrINKER 115; Opinion 853, 16 REPORT of N.Y.C.B.A. 488 (1961). 
of derivative suits, and thus may warrant a degree of protection. For example, a suit enjoining performance of a contract may affect employment and production in allied industries. More generally, to the extent that provision for effective and independent corporate counsel would facilitate the prosecution of meritorious derivative actions, the community interest in the prevention and punishment of corporate dishonesty would be furthered. ${ }^{\text {it }} \mathrm{A}$ second major concern is the preservation, wherever feasible, of the integrity of the corporation as a self-governing unit. The selection of corporate counsel and the supervision of his duties are clearly within the authority of the board of directors, who have been duly elected by the shareholders to run the corporation. Since the mere institution of a derivative suit is not a legal determination that the board is unfit to govern the corporation, it may be questioned whether judicial restriction of their authority over counsel is justifiable. A corollary concern, of course, is the competence of the courts to substitute their judgment, regarding the selection and supervision of corporate counsel, for that of the directors and officers. Finally, the costs of implementing procedures to provide the corporation with effective counsel must be taken into account. Such devices will demand added time and energy from the courts. At the same time, the financial burden derivative litigation places on the corporation may increase.

Since the values represented by these concerns all seem deserving of recognition, and since these values are in many respects incompatible, compromise is necessary in fashioning procedures to assure the corporation independent and effective counsel. ${ }^{22}$ The point of departure for these procedures must be the mode of counsel's selection. It seems essential that the power of implicated directors to choose the corporation's counsel be diminished. If there is a sufficient number of directors not party to the litigation, the court might permit only these directors to participate in the selection of counsel. Such disinterested directors need not be a majority of the board, for a committee could be allowed to make the selection. Although it may seem superficial to distinguish between interested and disinterested directors on the basis of their personal involvement in the suit, this device provides the courts with

61. For a classic statement of the idea that the modern business corporation has a responsibility not only to its shareholders but also to its employees, customers and the general public, see Dodd, For Whom are Corporate Managers Trustees?, 45 HARv. L. Rev. 1145 (1932).

62. The problem of providing the corporation with effective counsel is, of course, common to all derivative suits. Thus, even in cases in which the corporation is separately represented $a b$ initio, counsel may in reality be wholly subservient to the director and officer defendants. See Korman v. Mathias, 32 Ill. App. 2d 341, 177 N.E.2d 720 (1961). The procedures here suggested have been developed as a remedy to dual representation, and their fullest utility will be in cases where the courts feel that it is both advisable and practical to resolve dual representation by requiring the corporation to retain new counsel. Nevertheless, these procedures - with the possible exception of those regulating the method of counsel's selection - may hopefully submit to a broader application to all derivative suits, including those in which the corporate and insider defendants initially appear with separate counsel. 
an objective standard by which a director's suitability to participate in the selection of counsel may be determined. In cases where all or virtually all of the directors are party to the suit, as was the situation in Lewis, greater judicial supervision of counsel's selection should be required. A possible approach would be for the court to appoint counsel after consultation with the directors and officers of the corporation. Alternatively, appointment might be made by the court after the corporation, through its directors, submitted a list of acceptable counsel. In all cases, of course, whether selection be made by a committee of disinterested directors or by the court, the attorney or firm engaged should be one that has had no previous dealings with the corporation or with any of the individual insider defendants. ${ }^{63}$

Such a solution obviously permits the directors to retain considerable control over the choice of corporate counsel. In so doing, a degree of protection of shareholder interests may be sacrificed. But a respect for the traditional autonomy of the corporation compels this compromise. Any further restriction of the board's authority would also necessitate a corresponding increase in the court's role in the selection process. Aside from the fact that this would increase the burden on the courts, there are serious doubts whether the courts, as an institution, are capable of choosing the attorney who will be most responsive to a corporation's interests. ${ }^{64}$

Once counsel is selected, provision should be made to insure his retention for the duration of the litigation. Restriction of the board's power of dismissal would tend to shield counsel from a major source of pressure to subordinate the welfare of the corporation to the interests of the insider defendants. Of course there may be legitimate circumstances in which the corporation should be permitted to petition for counsel's removal, but such dismissal should be allowed only in instances where the corporation can demonstrate to the court incompetence or negligence on the part of counsel.

Provision must also be made to allow counsel access to information and data in the possession of the corporation. Unduly severe restrictions upon access would render it difficult for counsel to form an intelligent opinion regarding the proper position of the corporation in the actual litigation and in any settlement negotiations. The question then becomes one of determining what limitation, if any, should be placed upon counsel's right to demand access. Since an unlimited right of access would impose excessive burdens on the corporation, and since it might transform counsel into an independent investigator of all corporate dishonesty, it seems appropriate to limit counsel's access to information relevant to the transactions involved in the derivative

63. The Lewis court merely required that the independent counsel have had no previous connection with the corporation. It is clearly more important that counsel have had no substantial previous dealings with the insider defendants.

64. The largely unhappy experience in other areas in which there has developed a specialized bar of court appointed attorneys - to wit, bankruptcy and probate - casts further doubt upon a procedure giving the courts sole responsibility to name corporate counsel. 
suit. Such provision, of course, may present difficulties of administration. The limiting requirement of relevance to the subject matter of the suit, however, will hopefully confine counsel's investigation within reasonable bounds; in addition, it is probably not unrealistic to place reliance upon the good faith of counsel to refrain from engaging in an unnecessarily extensive investigation. Secondly, the limitation of relevancy should provide the courts with a general standard by which to settle any disputes that might arise over the counsel's right to access. In defining the scope of the term "relevance," courts will be able to draw helpful analogies from modern civil procedure acts where similar standards are provided for determination of a party's right to discovery. ${ }^{65}$ However, in settling access disputes it must be remembered that the independent counsel, unlike an adversary party, will have no motive to harass his corporate client by extravagant demands for information: Counsel's requests for access to information, though requiring some substantiation regarding relevance, consequently should be viewed with a presumption of legitimacy.

As a final proposal, the independent counsel should be required to prepare a brief memorandum setting forth his findings on the merits of the suit and his opinion as to the proper stance of the corporation in the litigation. Counsel's report would be filed with the court, and would be made available to all parties to the suit, as well as to any shareholder who requested a copy. The formal reporting by counsel would serve three purposes. It would subject his work product to critical public scrutiny, and through this deterrent effect decrease the possibility that counsel will harbor unspoken bias in favor of the insiders. ${ }^{\text {co }}$ It would formalize and render more public the process by which the corporation is advised of its appropriate role in the litigation, so that the board might be deterred from rejecting counsel's advice because of self-interest, at least to the extent of tending to prevent superficially disinterested directors from determining the corporation's role on the basis of personal ties with the insider defendants. Lastly, the attorney's memorandum should be included in any notice sent to the shareholders regarding possible settlement of the suit. ${ }^{67}$ This would provide the shareholders with an independent analysis of both the merits of the suit and the potential recovery that might derive from a successful prosecution. ${ }^{68}$

65. See FED. R. Civ. P. 26(b) \& 34.

66. In this respect, the independent counsel's memorandum opinion would be roughly analogous to the opinion prepared by a public accountant certifying a financial statement. To be meaningful, an accountant's certificate must be the work of an independent expert. And perhaps the most effective insurance that the certificate will be the product of independence is the fact that it is available to public scrutiny, with the consequent possibility that any false or misleading practice may be brought to light.

67. See note 48 supra.

68. The memorandum opinion of the independent counsel bears certain similarities to a procedure that may be instituted by the Board of Trade in Great Britzin. In a variety of circumstances - for example, where there are indications of oppression of minority shareholders or fraud or misconduct by the directors - the board may appoint an inspector to investigate the affairs of the company. Companies Act, 1948, $\S$ 164-75. The inspector, 
Hopefully these procedures will safeguard the selection and enhance the effectiveness of corporate counsel in derivative actions, thus affording an added measure of protection to the various interests represented by and dependent upon the corporation. It might be argued that more complete protection of these interests could be achieved by adding to the current proposal provisions to restrict the power of the board to reject the advice of the independent counsel. For example, in cases where there is no disinterested majority of directors the court might rule that the opinion of counsel would be binding upon the board. Alternatively, the court could appoint a receiver or guardian ad litem for the corporation wherever the board refused to accept the recommendations of counsel. Such procedures, however, mark a drastic inroad upon the autonomy of the corporation as they would, in effect, oust the board of directors from control of the litigation prior to a legal determination of the charges of wrongdoing. Nor is it clear, considering the important business judgments involved, that an attorney would be competent, or even willing, to exercise sole responsibility for determining the corporation's role in the litigation. These procedures would also place added burdens, especially in terms of expense, upon both courts and corporations. Weighing these considerations, it seems unwise to restrict the board's authority to reject the opinion of independent counsel. ${ }^{69}$ Within the framework of present derivative litigation the potential gains that might be derived from such a procedtre are not commensurate with the costs that would be incurred.

who is generally an independent barrister, solicitor, or accountant, reports to the board, and normally the report is published. Id. at $\S 168$. As Gower points out, the inspector's report "alone may cause the wrong to be remedied," but "if this does not suffice the report should at least provide the stockholder with essential ammunition." Gower, Some Contrasts Between British and Anerican Corporation Law, 69 Harv. L. Rev. 1369, 1388 (1956).

See also McDaniel, Ethical Problems of Counsel for Big Business: The Burden of Resolving Conflicting Interests, 38 A.B.A.J. 205, 207 (1952).

69. Admittedly, an anomalous situation may arise should the board of directors reject the memorandum opinion, for the independent counscl might be asked to represent the corporation in court in a manner which is inconsistent with his recommendations. It is not uncommon, however, for lawyers to continue to represent clients who have rejected their advice. The opinion envisaged in the current proposal would, of course, have the unique attribute of being filed in court and made available to the shareholders; but since all should be aware of counsel's obligation to follow the direction of the board, any varlance between the memorandum opinion and counsel's appearance for the corporation should be accepted as a matter of course.

The various means which might be employed to eliminate this possible anomaly in counsel's role would seriously detract from the proposals suggested in this Note. One means would be to remove the board's powers to reject counsel's opinion. As alrcady noted, this seems inadvisable. A second means would be to allow the corporation to retain a new attorney should the independent counsel's opinion be rejected. But such a procedure would involve additional and unnecessary expense to the corporation. Finally, the provision making counsel's opinion available to the court and shareholders might be dispensed with. It is submitted, however, that the need for public scrutiny of the memorandtum opinion far outweighs the need to eliminate the perceived minor inconsistencies in counsel's role. 